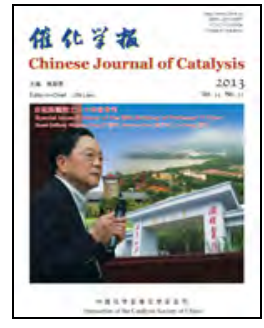

Article (Dedicated to Professor Yi Chen on the occasion of his 80th birthday)

\title{
Pathways between superoxide and peroxide species on small La-O clusters
}

\author{
Wensheng Xia*, Da Zhang, Weizheng Weng, Huilin Wan\# \\ State Key Laboratory of Physical Chemistry of Solid State Surfaces, National Engineering Laboratory for Green Chemical Productions of \\ Alcohols-Ethers-Esters, Fujian Province Key Laboratory of Theoretical and Computational Chemistry, College of Chemistry and Chemical Engineering, \\ Xiamen University, Xiamen 361005, Fujian, China
}

\section{A R T I C L E I N F O}

Article history:

Received 4 July 2013

Accepted 26 August 2013

Published 20 November 2013

\section{Keywords:}

Oxygen

Superoxide

Peroxide

Lanthanide oxide

Density functional theory

\begin{abstract}
A B S T R A C T
Density functional theory calculations were used to investigate the connection between superoxide and peroxide species on La-O clusters. In the singlet state, a superoxide species can transition into a peroxide species by moving through a substantial energy barrier via a series of ozonides. In the triplet state, there is no connection between the two species, although there are two paths (singlet and triplet) that allow the interaction and subsequent transformation of two superoxide molecules on a La-O cluster. The superoxide species readily transitions to a peroxide species through a triplet pathway $\left(\mathrm{O}_{2}{ }^{-}+\mathrm{O}_{2}{ }^{-} \leftrightarrow \mathrm{O}_{2}{ }^{2-}+\mathrm{O}_{2}\right)$, in which the superoxide species undergoes rapid exchange with the peroxide. In the singlet path, however, the superoxide species must move through a pronounced energy barrier to change into a peroxide species, demonstrating that these oxygen species are highly stable in the singlet state.
\end{abstract}

(C) 2013, Dalian Institute of Chemical Physics, Chinese Academy of Sciences. Published by Elsevier B.V. All rights reserved.

\section{Introduction}

Owing to the eventual depletion of oil resources and the ongoing price fluctuations of oil-derived products, the petrochemical industry will eventually be forced to use the cheaper and more abundant low molecular weight alkanes $\left(\mathrm{C}_{1}-\mathrm{C}_{4}\right)$ as feed stocks [1]. The selective catalytic oxidation of these compounds will therefore become an important aspect of modern industrial chemistry so as to allow the production of chemicals, monomers, and intermediates, which in turn will be used to make numerous products, including resins, plastics, paints, solvents, rubbers, and drugs.

It is anticipated that oxygen and its activation play an important role in the catalytic oxidation reactions of alkanes. The properties of various oxygen species, for example, may deter- mine product selectivity during the conversion of alkanes over metal oxides [2,3]. Various possible active oxygen species, such as $\mathrm{O}_{2}{ }^{2-}, \mathrm{O}_{2}{ }^{-}, \mathrm{O}^{-}$, and $\mathrm{O}^{2-}$, which are all quite different in nature, have been detected on oxide catalysts using spectroscopic methods of analysis [4]. Kazanskii and co-workers [5,6] noted that these oxygen species might exist in equilibrium with one another, depending on the nature of the catalyst, as in the following equation:

$$
\mathrm{O}_{2(\mathrm{~g})} \leftrightarrow \mathrm{O}_{2(\mathrm{ads})} \leftrightarrow \mathrm{O}_{2^{-}} \leftrightarrow \mathrm{O}_{2^{2-}} \leftrightarrow 2 \mathrm{O}^{-} \leftrightarrow 2 \mathrm{O}^{2-}
$$

$\mathrm{Au}$ et al. [7] have suggested that the interaction between $\mathrm{O}_{2}{ }^{2-}$ ions (observed via in situ Raman spectroscopy) and $\mathrm{CH}_{4}$ may generate carbene radicals, which would account for the highly selective nature of $\mathrm{BaCO}_{3} / \mathrm{LaOBr}$ catalysts during the synthesis of ethylene. Density functional theory (DFT) calculations performed by Palmer et al. [8] showed that peroxide

\footnotetext{
*Corresponding author. Tel: +86-592-3658107; Fax: +86-592-2183047; E-mail: wsxia@xmu.edu.cn

\#Corresponding author. E-mail: hlwan@xmu.edu.cn

This work was supported by the National Basic Research Program of China (973 Program, 2010CB732303), the National Natural Science Foundation of China (21033006, 21373169, 20373054), and the Program for Changiang Scholars and Innovative Research Team in the University (IRT1036). DOI: 10.1016/S1872-2067(12)60694-9 | http://www.sciencedirect.com/science/journal/18722067 | Chin. J. Catal., Vol. 34, No. 11, November 2013
} 
$\left(\mathrm{O}_{2}{ }^{2-}\right)$ species and $\mathrm{O}^{-}$species were the sources of active oxygen associated with the oxidative coupling of methane (OCM) over $\mathrm{La}_{2} \mathrm{O}_{3}(001)$ and $\mathrm{Sr}^{2+}$-doped surfaces. This result, however, appears to be contradicted by reports that a superoxide $\left(\mathrm{O}_{2}^{-}\right)$ species is involved in the OCM into $\mathrm{C}_{2} \mathrm{H}_{4}$ over $\mathrm{BaF}_{2}$ or $\mathrm{SrF}_{2}$ doped lanthanide oxide catalysts at $600-700{ }^{\circ} \mathrm{C}$ [4]. Because it has been detected over lanthanide oxide-based catalysts at high temperatures $\left(600-700{ }^{\circ} \mathrm{C}\right)$, the superoxide species appears to be reasonably stable. In the past, however, it was thought that $\mathrm{O}_{2}$ - could only play an active role in heterogeneous catalysis occurring at low temperatures because of its inherent lack of stability [9]. Lious et al. [10,11], for example, demonstrated the instability of the superoxide ion on $\mathrm{La}_{2} \mathrm{O}_{3}$ under OCM conditions. Diwald et al. [12] found infrared peaks and electronic paramagnetic resonance signals attributed to $\left(\mathrm{O}_{2}-\ldots \mathrm{OH}\right)$ over the surface of $\mathrm{MgO}$ nanoparticles exposed to a $\mathrm{H}_{2} / \mathrm{O}_{2}$ atmosphere in the absence of light. In a previous study [13], we used DFT calculations to demonstrate the formation of superoxide species and found that their stability on La-O clusters was related to various properties of the clusters. The stability of superoxide species was found to increase moving from positive to neutral and negatively charged clusters, such that superoxide species on positively charged or neutral La-O clusters were not as stable in a triplet state as in a singlet state, while those species on negatively charged clusters exhibited good stability in both the triplet and singlet states. Ferreira et al. [3] found that the quantity of basic sites, $\mathrm{CH}_{4}$ conversion rates, and selectivity for $\mathrm{C}_{2} \mathrm{H}_{6}$ and $\mathrm{C}_{2} \mathrm{H}_{4}$ were all controlled by the ratio of electrophilic oxygen species $\left(\mathrm{O}_{2}{ }^{-}\right.$and $\left.\mathrm{O}_{2}{ }^{2-}\right)$ to lattice oxygen $\left(\mathrm{O}^{2-}\right)$ on the surface of the catalyst at $700{ }^{\circ} \mathrm{C}$. The doping of alkaline metal $\left(\mathrm{Mg}, \mathrm{Ca}\right.$, and $\mathrm{Sr}$ ) into $\mathrm{CeO}_{2}$ catalysts has also been found to generate an abundance of electrophilic oxygen species $\left(\mathrm{O}_{2}{ }^{-}\right.$ and $\mathrm{O}_{2}{ }^{2-}$ ) on the catalyst surface. Moreover, the zeolite-like material $\mathrm{Ca}_{12} \mathrm{Al}_{10} \mathrm{Si}_{4} \mathrm{O}_{35}$ exhibits high activity for the oxidation of hydrocarbons owing to the presence of both superoxide and peroxide ions [14]. Using electronic spin resonance (ESR), Sachtler et al. $[15,16]$ demonstrated the formation of superoxide ions in a Fe/ZSM-5 zeolite at $-196{ }^{\circ} \mathrm{C}$ and found that as the temperature was increased, the superoxide ions were more likely to be converted into peroxide ions, which are not seen in the ESR spectra but are active in the Raman spectra $[17,18]$. It is therefore important to investigate the conversion of superoxide species over metal oxides.

In the present work, we attempted to link the transformation of superoxide species with the formation of peroxide species using DFT methods to provide additional insight into the transformations and interactions of oxygen species on metal oxides. Such information should be helpful when designing catalysts at the molecular level for the selective oxidation of alkanes.

\section{Methods and models}

We examined three gas clusters, $\left(\mathrm{LaO}_{x} \mathrm{H}\right)^{4-2 x}(x=1-3)$, to investigate the conversion of superoxide species to peroxide species. These same clusters had previously been used to investigate the formation and subsequent stability of superoxide spe- cies [13], but that work only examined the role of the neutral $\mathrm{LaO}_{2} \mathrm{H}$ cluster in the conversion of superoxide species to peroxides. We therefore chose the neutral clusters $\mathrm{LaO}_{2} \mathrm{H}$ and $\mathrm{La}_{2} \mathrm{O}_{3}$ as our models and used $\mathrm{La}_{2} \mathrm{O}_{3}$ to examine the interactions between oxygen species at different sites because such interactions can affect the further conversion of superoxide species.

Observations of neutral gas clusters generated using laser ablation have been reported $[19,20]$. Superoxide species were observed on the surfaces of $\mathrm{MgO}$ nanoparticles exposed to $\mathrm{H}_{2} / \mathrm{O}_{2}$ atmosphere [12], indicating that the presence of $\mathrm{OH}$ favors the formation of superoxides. For this reason, the gas clusters $\mathrm{LaO}_{2} \mathrm{H}$ and $\mathrm{La}_{2} \mathrm{O}_{3}$ were used in an attempt to elucidate the transformations and interactions of oxygen species over lanthanum oxides.

All calculations were performed with the Gaussian 98 set of programs [21] within the framework of spin-unrestricted hybrid DFT (B3PW91), using Becke's three parameter exchange functional with the local correlation part provided by Vosko, Wilk, and Nusair [22] and the non-local correlation part by Perdew and Wang's 1991 gradient-corrected functional $[23,24]$. The basis set applied to the La center was LANL2DZ (Los Alamos effective core potential plus a double zeta), in which the Hay-Wadt [25] relativistic effective core potential based on numerical relativistic Hartree-Fock atomic wave functions is considered. A 6-31+G(d,p) basis set [26] was used for all the remaining centers. Full optimizations of geometry for all local minima and transition states were performed without any constraints, followed by intrinsic reaction coordinate computations to confirm the transition states connected with the appropriate minima on the potential energy surfaces.

\section{Results and discussion}

The energy diagram along various pathways associated with oxygen interactions with La-O clusters, as computed at the spin unrestricted B3PW91/6-31+G(d,p)+LanL2DZ level, is shown in Fig. 1. The B3PW91/6-31+G(d,p)+LanL2DZ-calculated scaled vibrational frequencies of the selected species (scale factor: 0.94) are presented in Table 1 . The optimized geometries of various oxygen species along their transformations are depicted in Fig. 2.

As shown in Table 1, the $0-0$ bond length in the groundstate $\mathrm{O}_{2}(\mathrm{~T})$ is predicted to be $1.208 \AA$, and the associated vibrational frequency is $1584.7 \mathrm{~cm}^{-1}$. In comparison, the experimentally derived values are $1.208 \AA$ and $1580.1 \mathrm{~cm}^{-1}$ [27]. The $\mathrm{O}_{2}{ }^{-}$ species has a calculated $0-0$ bond length of $1.339 \AA$ and a vibrational frequency of $1137.9 \mathrm{~cm}^{-1}$, both of which are in good agreement with experimental values $(1.348 \pm 0.008 \AA$ and $1108 \pm 20 \mathrm{~cm}^{-1}$ ). The energy difference between $\mathrm{O}_{2}(\mathrm{~T})$ and $\mathrm{O}_{2}-$ is calculated to be $10.45 \mathrm{kcal} / \mathrm{mol}$, which is close to the experimentally obtained value of $0.45 \mathrm{eV}(10.38 \mathrm{kcal} / \mathrm{mol})$ [28]. The $\mathrm{O}-\mathrm{O}$ bond length in $\mathrm{O}_{2}{ }^{2-}$ is $1.546 \AA$, and the vibration frequency is of $691.9 \mathrm{~cm}^{-1}$. The calculated bond length is close to the value of $1.55 \AA$ [29] derived from GGA-PW91 calculations of $\mathrm{O}_{2}{ }^{{ }^{-}}$on $\mathrm{MgO}$ and the experimentally determined bond length of 1.464 $\AA$ found for $\mathrm{H}_{2} \mathrm{O}_{2}$ [30], while the experimentally obtained vibra- 


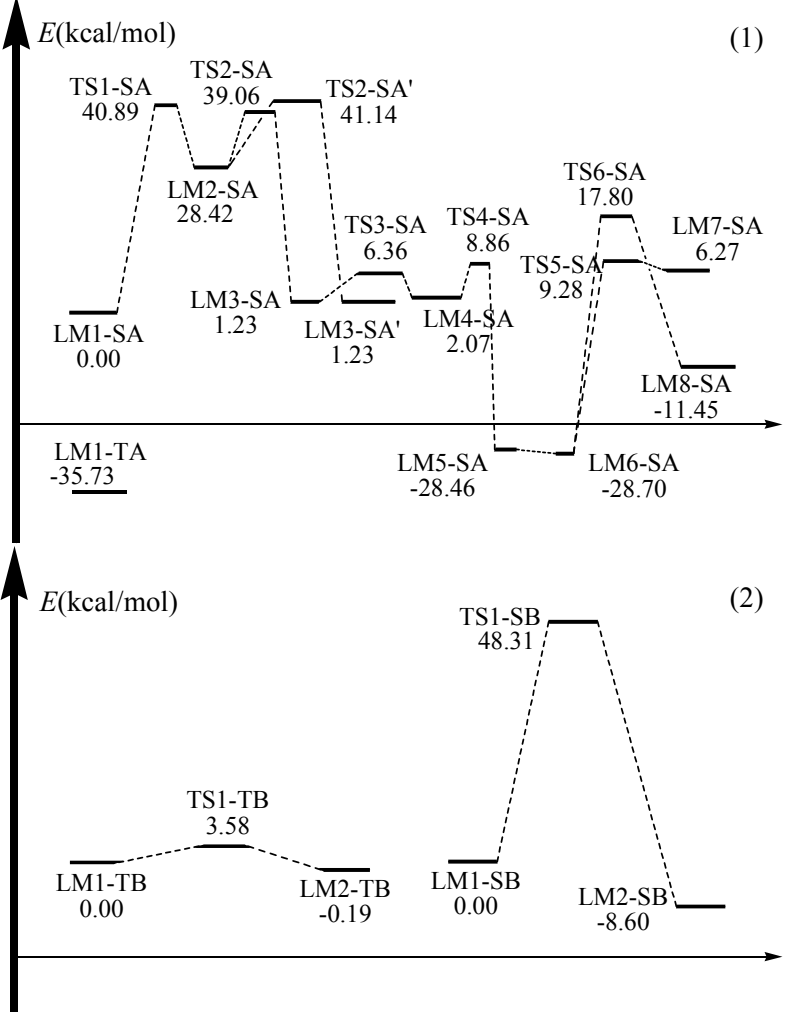

Fig. 1. The predicted potential energy surfaces involved in the transformations of oxygen species on $\mathrm{LaO}_{2} \mathrm{H}(1)$ and $\mathrm{La}_{2} \mathrm{O}_{3}(2)$ clusters at the spin-unrestricted B3PW91/6-31+G(d,p)+LanL2DZ level.

tional frequency of the $0-0$ bond in $\mathrm{H}_{2} \mathrm{O}_{2}$ is $890 \mathrm{~cm}^{-1}$ [31]. The results of DFT calculations at the B3PW91 level therefore appear to be satisfactory.

\subsection{Evolution of single superoxide species to peroxide species}

In principle, it is possible for $\mathrm{O}_{2}$ in its singlet (S) state to transform into superoxide $\left(\mathrm{O}_{2}{ }^{-}\right)$or peroxide species $\left(\mathrm{O}_{2}{ }^{2-}\right)$ or for $\mathrm{O}_{2}$ in its triplet (T) state to transform into the superoxide with conservation of spin, but it is spin-forbidden for $\mathrm{O}_{2}$ in the triplet state to change into peroxide species $\left(\mathrm{O}_{2}{ }^{2-}\right)$ because spin is not conserved. These scenarios are summarized below.

Spin-allowed (X(S) indicates a single state):

$$
\begin{aligned}
& \mathrm{O}_{2}(\mathrm{~T})+\mathrm{X}(\mathrm{S}) \leftrightarrow \mathrm{O}_{2}-\left({ }^{\uparrow} \mathrm{D}\right)+\mathrm{X}^{+}\left({ }^{\uparrow} \mathrm{D}\right) \text { or } \mathrm{O}_{2}{ }^{-}\left({ }^{\top} \mathrm{D}\right)-\mathrm{X}^{+}\left({ }^{\top} \mathrm{D}\right) \\
& \left.\left.\mathrm{O}_{2}(\mathrm{~S})+\mathrm{X}(\mathrm{S}) \leftrightarrow \mathrm{O}_{2}-{ }^{\top} \mathrm{D}\right)+\mathrm{X}^{+}\left({ }_{\downarrow} \mathrm{D}\right) \text { or } \mathrm{O}_{2}-{ }^{\uparrow} \mathrm{D}\right)-\mathrm{X}^{+}\left({ }_{\downarrow} \mathrm{D}\right) \\
& \mathrm{O}_{2}(\mathrm{~S})+\mathrm{X}(\mathrm{S}) \leftrightarrow \mathrm{O}_{2}{ }^{2-}(\mathrm{S})+\mathrm{X}^{2+}(\mathrm{S}) \text { or } \mathrm{O}_{2}{ }^{2-}(\mathrm{S})-\mathrm{X}^{2+}(\mathrm{S})
\end{aligned}
$$

Spin-forbidden:

$$
\mathrm{O}_{2}(\mathrm{~T})+\mathrm{X}(\mathrm{S}) \leftrightarrow \mathrm{O}_{2}{ }^{2-}(\mathrm{S})+\mathrm{X}^{2+}(\mathrm{S}) \text { or } \mathrm{O}_{2}{ }^{2-}(\mathrm{S})-\mathrm{X}^{2+}(\mathrm{S})
$$

The $\mathrm{O}_{2^{-}}$ion is in the doublet state (D), but the resulting $\mathrm{O}_{2}-(\mathrm{D})-\mathrm{X}^{+}(\mathrm{D})$ complex could be in either the singlet (S) or triplet state $(\mathrm{T})$ when $\mathrm{O}_{2}(\mathrm{~S}, \mathrm{~T})$ interacts with $\mathrm{X}(\mathrm{S})$ in the singlet state, where $\mathrm{X}(\mathrm{S})$ stands for La-O clusters in the singlet state.

For the molecular oxygen species LM1-TA produced from the interaction of $\mathrm{O}_{2}(\mathrm{~T})$ with the $\mathrm{LaO}_{2} \mathrm{H}$ cluster, the $\mathrm{O}-\mathrm{O}$ bond stretching frequency is $1152.3 \mathrm{~cm}^{-1}$ and the $\mathrm{O}-0$ bond length is $1.317 \AA$ (Table 1), both of which are very close to the values of $1125.8 \mathrm{~cm}^{-1}$ and $1.339 \AA$ for the gaseous superoxide anion $\mathrm{O}_{2}$. The $\mathrm{La}(\mathrm{O})-\mathrm{OH}$ bond length in LM1-TA is also decreased to $2.193 \AA$ from $2.232 \AA$ in $\mathrm{LaO}_{2} \mathrm{H}$. Thus, the bidentate LM1-TA species is considered to be a superoxide species $\left(\left(\eta^{2}\right.\right.$-superoxide)- $\mathrm{LaO}_{2} \mathrm{H}$ ). However, we do not find any evidence for any additional evolution of this superoxide species in the triplet state (Fig. 1(1)).

The species LM1-SA, formed from oxygen $\mathrm{O}_{2}(\mathrm{~S})$ and the $\mathrm{LaO}_{2} \mathrm{H}$ cluster, is also assigned as a bidentate superoxide species $\left(\left(\eta^{2}\right.\right.$-superoxide)- $\left.\mathrm{LaO}_{2} \mathrm{H}\right)$. Its $\mathrm{O}-\mathrm{O}$ bond stretching frequency is predicted to be $1226.9 \mathrm{~cm}^{-1}$, with an $0-0$ bond dis-

\begin{tabular}{|c|c|c|c|c|c|c|}
\hline \multirow{2}{*}{ Schematic } & \multirow{2}{*}{ Species } & \multirow{2}{*}{ O-O bond length $(\AA)$} & \multirow{2}{*}{$2 S+1$} & \multicolumn{2}{|c|}{ Frequencies $\left(\mathrm{cm}^{-1}\right)$} & \multirow{2}{*}{ Identity } \\
\hline & & & & $\left(\mathrm{O}_{3}\right)$ & $(0-0)$ & \\
\hline & $\mathrm{O}_{2}(\mathrm{~T})$ & 1.208 & 3 & & 1567.9 & $\mathrm{O}_{2}$ \\
\hline & $\mathrm{O}_{2}(\mathrm{~S})$ & 1.208 & 1 & & 1556.2 & $\mathrm{O}_{2}$ \\
\hline & $\mathrm{O}_{2}{ }^{2-}$ & 1.339 & 2 & & 1125.8 & $\mathrm{O}_{2^{-}}^{-}$ \\
\hline & $\mathrm{O}_{2}^{2-}$. & 1.546 & 1. & & 684.6 & $\mathrm{O}_{2}^{2-}$ \\
\hline & $\mathrm{O}_{3}{ }^{2-}$ & $1.472,1.472$ & 1 & $411.9,620.8,791.5$ & & ozone \\
\hline & LM1-TA & 1.317 & 3 & & 1152.3 & $\mathrm{O}_{2}^{-}$ \\
\hline & LM1-SA & 1.270 & 1 & & 1226.9 & $\mathrm{O}_{2^{-}}^{-}$ \\
\hline & LM8-SA & $1.477,1.470$ & 1 & & $812.8,832.6$ & $2 \mathrm{O}_{2}{ }^{2^{-}}$ \\
\hline & LM1-TB & $1.323,1.329$ & 3 & & $1148.2,1156.5$ & $2 \mathrm{O}_{2^{-}}^{-}$ \\
\hline & LM2-TB & $1.209,1.489$ & 3 & & $1574.3,821.1$ & $\mathrm{O}_{2}+\mathrm{O}_{2}^{2-}$ \\
\hline & LM1-SB & $1.251,1.300$ & 1 & & $1263.5,1127.4$ & $\mathrm{O}_{2}^{-}+\mathrm{O}_{2}^{-}$ \\
\hline & LM2-SB & $1.486,1.272,1.489$ & 1. & & $828.6,1248.7,815.4$ & $2 \mathrm{O}_{2}^{2-}+\mathrm{O}_{2}^{-}$ \\
\hline & LM2-SA & $1.452,1.452$ & 1 & $475.3,682.7,792.4$ & & ozonide \\
\hline & LM3-SA' & $1.375,1.527$ & 1 & $295.7,578.8,912.9$ & & ozonide \\
\hline & LM3-SA & $1.379,1.546$ & 1 & $328.6,577.4,913.4$ & & ozonide \\
\hline & LM4-SA & $1.421,1.442$ & 1 & $471.3,729.9,864.6$ & & ozonide \\
\hline & LM5-SA & $1.460,1.461$ & 1 & $528.5,670.1,828.0$ & & ozonide \\
\hline & LM6-SA & $1.466,1.466$ & 1 & $543.8,675.3,825.2$ & & ozonide \\
\hline & LM7-SA & $1.404,1.470$ & 1 & $509.4,695.5,906.5$ & & ozonide \\
\hline
\end{tabular}

Table 1

The characteristic vibrational frequencies of $\mathrm{O}_{3}$ and $\mathrm{O}_{2}$ species involved in oxygen transformation on La-O clusters as predicted at the spin-unrestricted B3PW91 level (scaled factor: 0.94). 


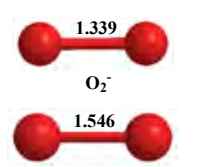

$\mathrm{O}_{2}{ }^{2-}$

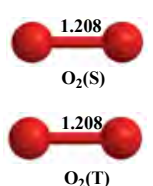

$\mathrm{O}_{2}(\mathrm{~T})$

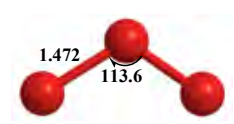

$\mathrm{O}_{3}{ }^{2-}$

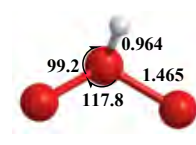

$\mathrm{HO}_{3}^{-}(\mathbf{1})$

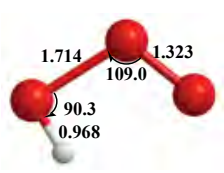

$\mathrm{HO}_{3}^{-}{ }^{-(2)}$
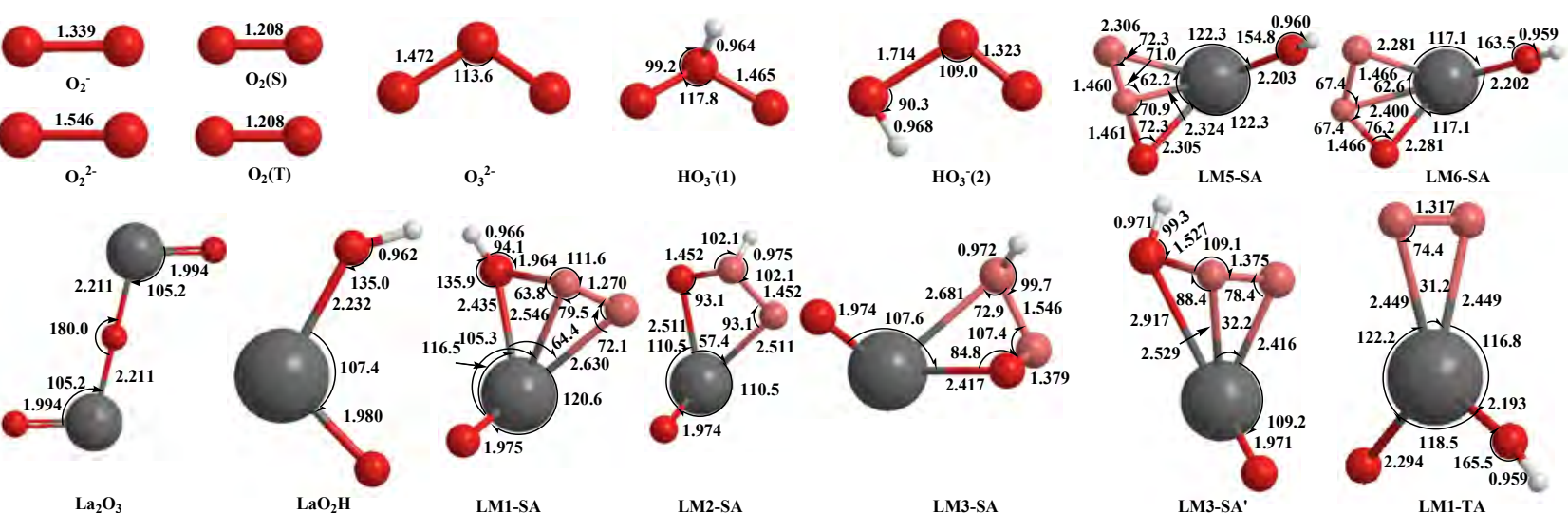

LM2-SA LM3-SA
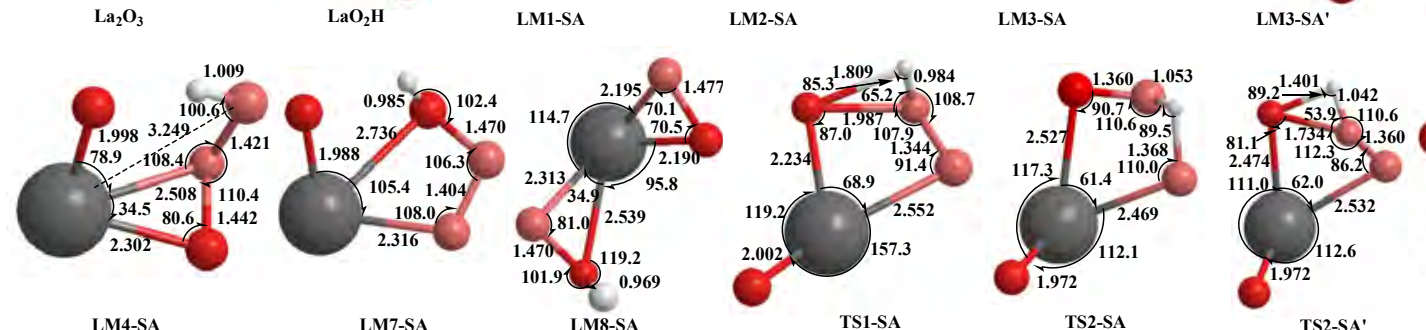

LM1-TA
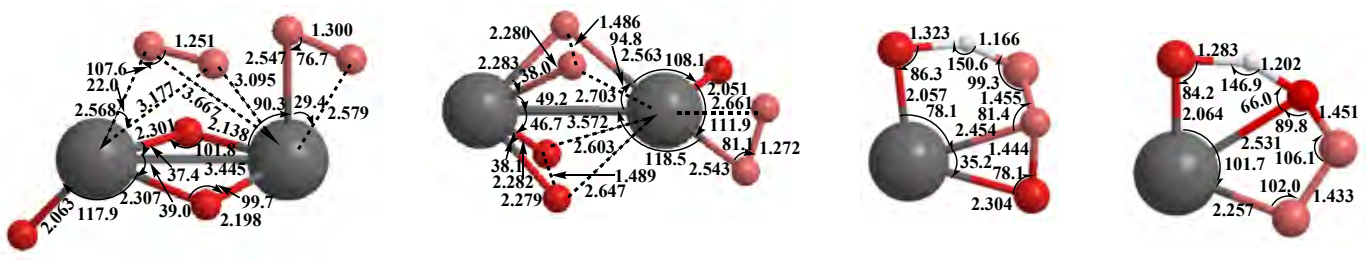

LM1-SB
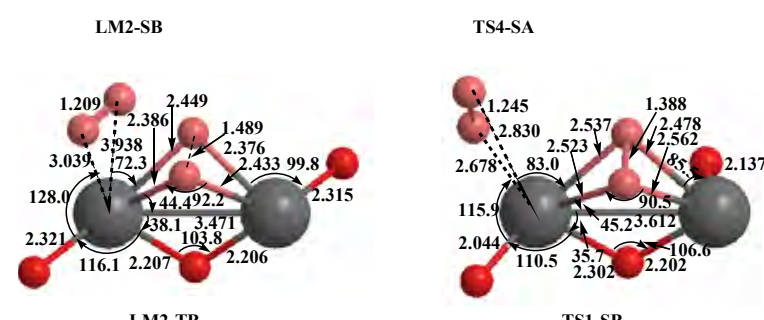

TS5-SA
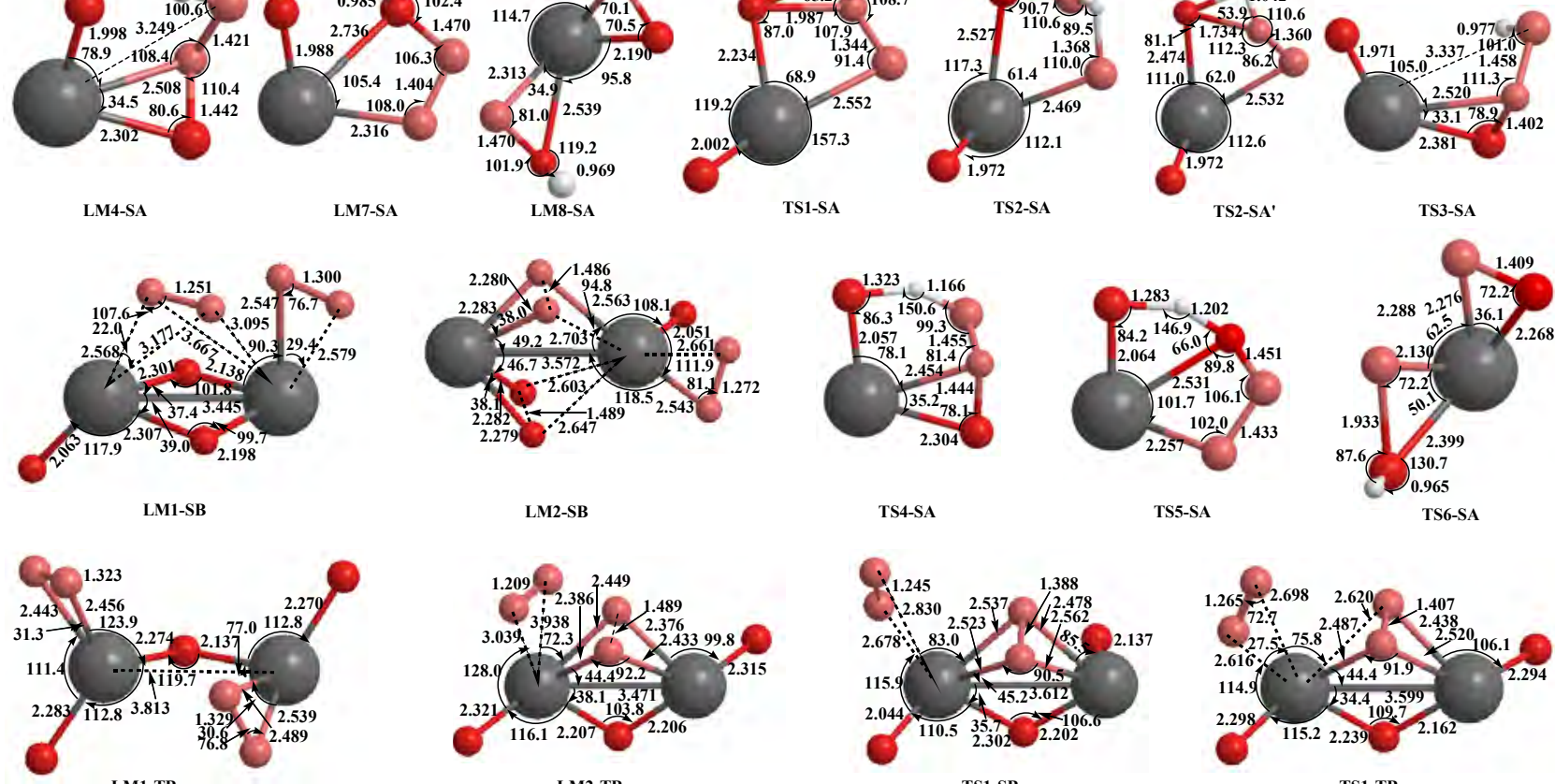

LM1-TB

LM2-TB

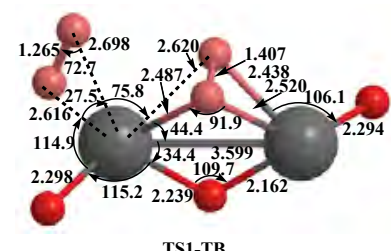

TS1-TB

Fig. 2. The optimized geometries of local minima and transition states involved in oxygen species transformations on $\mathrm{LaO}_{2} \mathrm{H}_{\text {and }} \mathrm{La}_{2} \mathrm{O}_{3}$ clusters at the spin-unrestricted B3PW91/6-31+G(d,p)+LanL2DZ level.

tance of $1.270 \AA$ A. The La(0)-OH bond length in LM1-SA is increased to $2.435 \AA$ from $2.232 \AA$ in $\mathrm{LaO}_{2} \mathrm{H}$. As shown in Fig. $1(1)$, the further evolution of the superoxide species LM1-SA ( $\left(\eta^{2}\right.$-superoxide) $\left.-\mathrm{LaO}_{2} \mathrm{H}\right)$ in the singlet state has to overcome an energy barrier of $40.89 \mathrm{kcal} / \mathrm{mol}$ associated with the TS1-SA transition state to produce the species LM2-SA $\left(\left(\eta^{2}-\mathrm{HO}_{3}\right)-\mathrm{LaO}\right)$. During this transition process, the $\mathrm{H}$ atom in $\mathrm{LaO}_{2} \mathrm{H}$ is transferred to the dioxygen moiety, and this dioxygen group bonds to the bridged oxygen in $\mathrm{LaO}_{2} \mathrm{H}$. The bond lengths of the two $\mathrm{O}-0$ bonds in the $\mathrm{O}-\mathrm{O}(\mathrm{H})-\mathrm{O}$ group are $1.452 \AA$, and the $\mathrm{La}(0)-0$ bond length in $\mathrm{LaO}_{2} \mathrm{H}$ increases to 2.511 Å from 2.232 $\AA$ in the $\mathrm{LaO}_{2} \mathrm{H}$. The resulting LM2-SA species is a form of ozonide (cf. the geometry of $\mathrm{HO}_{3}^{-}$(1) in Fig. 2).

LM2-SA can be converted into other ozonide species (LM3-SA, LM3-SA', LM4-SA, LM5-SA, and LM6-SA) in a stepwise manner involving low activation energy barriers $(<13.0$ $\mathrm{kcal} / \mathrm{mol}$, see Fig. 1(1) and Table 1). These pathways may be summarized as follows. (1) The $\mathrm{H}$ in the $\mathrm{O}-\mathrm{O}(\mathrm{H})-\mathrm{O}$ moiety is transferred to one of the neighboring oxygen centers, leading to the formation of LM3-SA via transition state TS2-SA, or to LM3-SA' via TS2-SA'. The species LM3-SA and LM3-SA' are considered to be $\mathrm{HO}_{3}$-like species because their geometry is comparable to that of $\mathrm{HO}_{3}^{-}(2)$ in Fig. 2. (2) LM3-SA is changed to LM4-SA via transition state TS3-SA as the distance between $\mathrm{OH}$ and the La center increases. (3) LM4-SA is converted to LM5-SA via transition state TS4-SA as the $\mathrm{H}$ in the $\mathrm{HO}_{3}$ moiety is transferred to the end-on oxygen bonded to the La center. The LM5-SA structure has the appearance of an $\mathrm{O}_{3}$ moiety bonded to the La center, in which the distance between the $\mathrm{O}_{3}$ moiety and the La center is about $2.31 \AA$, while the $0-0$ bond length in the $\mathrm{O}_{3}$ moiety of LM5-SA is about $1.460 \AA$ (cf. $1.472 \AA$ for $\mathrm{O}_{3}{ }^{2-}$ in Fig. 2). (4) LM5-SA relaxes to form LM6-SA with no activation energy barrier because there is little difference between the two structures.

Once formed, LM6-SA $\left(\left(\eta^{3}-\mathrm{O}_{3}\right)-\mathrm{LaOH}\right)$ can change into LM8-SA via transition state TS6-SA (with a barrier of 46.47 
$\mathrm{kcal} / \mathrm{mol}$ ) or into LM7-SA via TS5-SA (with a barrier of 37.98 $\mathrm{kcal} / \mathrm{mol}$ ). The latter transition is attributed to $\mathrm{H}$ transfer to the $\mathrm{O}_{3}$ moiety with the concurrent formation of an $\mathrm{HO}_{3}$ group, while the former is associated with the cleavage of the $0-00$ bond in $\mathrm{O}_{3}$, after which the remaining oxygen is transferred and a new dioxygen moiety is formed at the La center. The LM7-SA in structure is very similar to that of LM3-SA. LM8-SA consists of two dioxygen moieties around a La center, and the $\mathrm{O}-\mathrm{O}$ bond lengths in the two dioxygen groups are 1.477 and $1.470 \AA$. Based on the data in Table 1, these are considered to be peroxide species with $0-0$ bond frequencies of 812.8 or $832.6 \mathrm{~cm}^{-1}$ (( $\eta^{2}$-peroxide)-La- $\left(\eta^{2}\right.$-peroxide-H $\left.)\right)$, which is consistent with the observation of peroxide species at approximately $840 \mathrm{~cm}^{-1}$ over lanthanide oxide $[32,33]$. The peroxide species on LM8-SA originate from the oxygen of the La-O cluster and incoming $\mathrm{O}_{2}$. Similarly, Palmer et al. [8] used DFT calculations to show that peroxide species could be generated by the dissociative adsorption of $\mathrm{O}_{2}$ across the oxide surface of $\mathrm{La}_{2} \mathrm{O}_{3}(001)$.

The superoxide species (LM1-SA) is therefore linked to the peroxide species (LM8-SA) through several forms of ozonide species in the singlet state. The rate-determining step in this process is the transformation of LM6-SA into LM8-SA with an associated energy barrier of $46.47 \mathrm{kcal} / \mathrm{mol}$. Thermodynamically, LM8-SA is lower in energy than LM1-SA by 11.45 $\mathrm{kcal} / \mathrm{mol}$, and the peroxide species is thus more stable than the superoxide species.

We therefore believe that the transformation of single oxygen species on the neutral $\mathrm{LaO}_{2} \mathrm{H}$ clusters occurs according to the following scheme.

Singlet channel (S):

( $\eta^{2}$-superoxide) $-\mathrm{LaO}_{2} \mathrm{H} \leftrightarrow\left(\eta^{3}\right.$-ozonide $)-\mathrm{LaOH} \leftrightarrow$ $\left(\eta^{2}\right.$-peroxide $)$-La- $\left(\eta^{2}\right.$-peroxide-H $)$

Triplet channel (T):

$\left(\eta^{2}\right.$-superoxide) $-\mathrm{LaO}_{2} \mathrm{H} \leftarrow x \rightarrow$ peroxide- $\mathrm{LaO}_{2} \mathrm{H}$

Notably, peroxide $\left(\mathrm{O}_{2}{ }^{2-}\right)$ species are formed when oxygen on lanthanide sesquioxide undergoes laser irradiation [32,33], which is not in conflict with our prediction that the singlet superoxide species obtained from oxygen on La-O clusters could be transformed into the peroxide species.

\subsection{Interactions of two superoxide species and their transformation}

The interactions between oxygen species and their effects on oxygen species transformation should be considered because low oxygen pressures do not normally occur in normal circumstances. If one considers the interactions between two superoxide species, two spin paths (the singlet and triplet) for transformations at the La-O cluster should be taken into consideration in theory. In this study, we chose a simple $\mathrm{La}_{2} \mathrm{O}_{3}$ cluster with two La centers as our model when considering the nature of this transition.

\subsubsection{Oxygen species interactions in a singlet pathway}

As noted above, in the singlet state, superoxide species resulting from oxygen approaching the La-O cluster are relatively stable, so it is reasonable to consider the interactions between two superoxide species. According to Table 1 and Fig. 2, LM1-SB has vibrational frequencies of 1256.3 and $1127.4 \mathrm{~cm}^{-1}$, which are within the range of characteristic vibrational frequencies of superoxide species. The frequencies 1256.3 and $1127.4 \mathrm{~cm}^{-1}$ correspond to the $0-0$ bonds of incoming two dioxygen species with bond lengths of 1.251 and $1.300 \AA$, respectively. LM1-SB is therefore considered to consist of two superoxide species on the La-O cluster ([2( $\eta^{2}$-superoxide)]- $\mathrm{La}_{2} \mathrm{O}_{3}$ ), in which the $\mathrm{La}_{2} \mathrm{O}_{3}$ moiety must have a different structure from the free $\mathrm{La}_{2} \mathrm{O}_{3}$ cluster to maintain the LM1-SB complex in the singlet state. As the two superoxide species interact, LM1-SB will transform into LM2-SB via transition state TS1-SB if it can overcome the energy barrier of $48.31 \mathrm{kcal} / \mathrm{mol}$ (see Fig. 1(2)). The species LM2-SB has characteristics of both superoxide and peroxide species because it exhibits characteristic vibrational frequencies of $1248.7,828.6$, and $815.4 \mathrm{~cm}^{-1}$ with $\mathrm{O}-\mathrm{O}$ bond lengths of $1.272,1.486$, and $1.489 \AA$, respectively. Because LM2-SB is lower in energy than LM1-SB by 8.60 $\mathrm{kcal} / \mathrm{mol}$, the transition from LM1-SB to LM2-SB is exothermic.

During the conversion of LM1-SB into LM2-SB, one of the superoxide species undergoes only minimal change and behaves as a spectator, while the other superoxide is converted into a peroxide species. The terminal oxygen of the $\mathrm{La}_{2} \mathrm{O}_{3}$ cluster moves close to the bridged oxygen to maintain the LM2-SB complex in a singlet state, resulting in the formation of the peroxide species within the $\mathrm{La}_{2} \mathrm{O}_{3}$ cluster. As a result, external oxygen is transformed into a peroxide species concurrent with the relaxation of $\mathrm{La}-\mathrm{O}$ bonds inside the $\mathrm{La}_{2} \mathrm{O}_{3}$ cluster. This process is similar to the transformation of a single superoxide species on the $\mathrm{LaO}_{2} \mathrm{H}$ cluster as discussed above, although it differs with regard to the conversion mechanism. In the former case, the superoxide species is directly transformed into the peroxide in the presence of another superoxide species that acts as a spectator, while in the latter the superoxide species is converted into peroxide via an ozonide intermediate, as shown below:

$$
\begin{gathered}
{\left[2\left(\eta^{2} \text {-superoxide }\right)\right]-\mathrm{La}_{2} \mathrm{O}_{3} \leftrightarrow \eta^{2} \text {-superoxide }} \\
\left(\eta^{2} \text {-superoxide }\right)-\mathrm{LaO}_{2} \mathrm{H} \leftrightarrow\left(\eta^{3}-\mathrm{O}_{3}\right)-\mathrm{LaOH} \leftrightarrow \\
\left(\eta^{2} \text {-peroxide)-La- }\left(\eta^{2} \text {-peroxide- } \mathrm{H}\right)\right.
\end{gathered}
$$

\subsubsection{Oxygen species interactions in a triplet pathway}

If two superoxide species on a La-O cluster approach and interact with one another, the spin multiplicity may be 3 (triplet) owing to relaxation of the La-O clusters, as shown below.

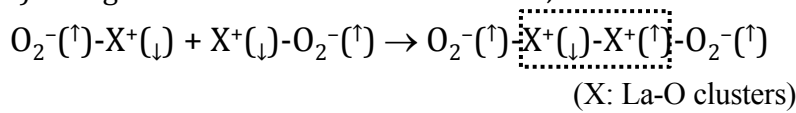

According to the data in Table 1 and Fig. 1(2), LM1-TB is a triplet species composed of two superoxide species on the $\mathrm{La}_{2} \mathrm{O}_{3}$ cluster, characterized by two vibrational frequencies of 1148.2 and $1156.5 \mathrm{~cm}^{-1}$, comparable to the $1125.8 \mathrm{~cm}^{-1}$ frequency of $\mathrm{O}_{2}{ }^{-}$. The two superoxide species of LM1-TB $\left(2\left(\eta^{2-}\right.\right.$ superoxide)- $\mathrm{La}_{2} \mathrm{O}_{3}$ ) interact with each other and LM1-TB forms LM2-TB via transition state TS1-TB, a process which involves a 
small barrier of around $4 \mathrm{kcal} / \mathrm{mol}$. LM2-TB is believed to be composed of a peroxide species and molecular oxygen (i.e., $\left(\eta^{2}\right.$-peroxide)- $\left.\mathrm{La}_{2} \mathrm{O}_{3}+\mathrm{O}_{2}\right)$, with vibrational frequencies of 821.1 and $1574.3 \mathrm{~cm}^{-1}$ (cf. $684.6 \mathrm{~cm}^{-1}$ of $\mathrm{O}_{2}{ }^{2-}$ and $1567.9 \mathrm{~cm}^{-1}$ of gaseous $\mathrm{O}_{2}(\mathrm{~T})$ ). The $\mathrm{O}-\mathrm{O}$ bond length of the peroxide species is predicted to be $1.489 \AA$, which is close to the value obtained experimentally (1.52 $\AA$ ) for the peroxide species on an $\mathrm{MgO}$ surface [29]. Its two oxygen atoms are situated across the two La centers of the $\mathrm{La}_{2} \mathrm{O}_{3}$ cluster. Their distance from the La atoms of the $\mathrm{La}_{2} \mathrm{O}_{3}$ cluster is approximately 2.376-2.449 $\AA$ (see Fig. 2), indicating the formation of $\mathrm{La}-\mathrm{O}$ bonds and comparable to the length of a La-O single bond $(\sim 2.211 \AA)$ in the $\mathrm{La}_{2} \mathrm{O}_{3}$ cluster. Another oxygen species in LM2-TB is $\mathrm{O}_{2}(\mathrm{~T})$, which undergoes negligible interactions with the $\mathrm{La}_{2} \mathrm{O}_{3}$ cluster, as the bond length between the oxygen species and the La-O cluster is in the range of 3.039-3.938 $\AA$. The $\mathrm{La}_{2} \mathrm{O}_{3}$ moieties in LM1-TB, TS1-TB, and LM2-TB are not much different in structure from the free $\mathrm{La}_{2} \mathrm{O}_{3}$ cluster, except for the slightly increased La-O bond length and the decreased $\mathrm{La}-\mathrm{O}-\mathrm{La}$ bond angles. The two superoxide species on the $\mathrm{La}_{2} \mathrm{O}_{3}$ cluster (LM1-TB) are thus disproportionately converted into peroxide species and molecular oxygen in the triplet state (LM2-TB).

It is worth noting that LM2-TB is lower in energy than LM1-TB by $0.19 \mathrm{kcal} / \mathrm{mol}$, meaning that the peroxide-related species is just slightly more stable than the superoxide, whereas the opposite is true in the case of the gas phase, where $2 \mathrm{O}_{2}{ }^{-}$ (g) $\rightarrow \mathrm{O}_{2}{ }^{2-}(\mathrm{g})+\mathrm{O}_{2}(\mathrm{~T})(\mathrm{g}), \Delta H=174.5 \mathrm{kcal} / \mathrm{mol}$. The superoxide and peroxide species on the La-O clusters are therefore in a state of rapid exchange when within the triplet state, as shown in Fig. 1(2) and as summarized below.

$$
\begin{gathered}
{\left[2\left(\eta^{2} \text {-superoxide }\right)\right]-\mathrm{La}_{2} \mathrm{O}_{3} \rightarrow\left(\eta^{2} \text {-peroxide }\right)-\mathrm{La}_{2} \mathrm{O}_{3}+\mathrm{O}_{2}(\mathrm{~T})} \\
\Delta H=-0.19 \mathrm{kcal} / \mathrm{mol}
\end{gathered}
$$

Recently, Huacuja et al. [34] investigated the reactivity of a $\mathrm{Pd}(\mathrm{I})-\mathrm{Pd}(\mathrm{I})$ dimer with $\mathrm{O}_{2}$ and indicated that a monohapto palladium superoxide complex was in equilibrium with a dipalladium peroxide complex.

It would be interesting to compare the energetics of the interactions of two superoxide species in the two pathways (singlet and triplet). The activation barrier associated with the conversion of peroxide species back into superoxide species is quite high in the singlet path, as shown in Fig. 1(2), and so the peroxide species will be rather stable in the singlet path. How- ever, the peroxide species is in rapid exchange with the superoxide species in the triplet path.

Experimentally, peroxide $\left(\mathrm{O}_{2}{ }^{2-}\right)$ species have been detected when oxygen on lanthanide sesquioxide is exposed to laser irradiation $[32,33]$. Because the irradiated oxygen is believed to be in the singlet rather than the triplet or ground state, this finding is in good agreement with our predicted results. In addition, it has been observed that the band associated with $\mathrm{O}_{2}{ }^{-}$ species over $\mathrm{BaF}_{2} / \mathrm{LaOF}$ first increased then disappeared during the conversion of $\mathrm{CH}_{4}$ into $\mathrm{C}_{2} \mathrm{H}_{4}$ [4]. Calculations by Palmer et al. [8], however, indicate that a peroxide species is the main active oxygen source in the oxidative coupling of methane. These seemingly inconsistent findings can be reconciled if we consider our predicted rapid exchange between the superoxide and peroxide species in the triplet path. One possible explanation is that $\mathrm{O}_{2}-$ may react with $\mathrm{CH}_{4}$ to form $\mathrm{C}_{2}$ species at high temperatures and low oxygen coverage, but at low temperatures and high oxygen coverage $\mathrm{O}_{2}{ }^{-}$is rapidly converted into $\mathrm{O}_{2}{ }^{2-}$, which subsequently reacts with $\mathrm{CH}_{4}$ to produce $\mathrm{C}_{2}$ species.

Cho et al. [35] reported that the reactivity of a $\mathrm{Cr}$ (III)-superoxide complex with activated $\mathrm{C}-\mathrm{H}$ bonds occurred via a $\mathrm{H}$-atom abstraction mechanism, so we believe that a superoxide can be the active oxygen species in methane dehydrogenation if it is sufficiently stable. Ferreira et al. [3] reported that alkaline metal $(\mathrm{Mg}, \mathrm{Ca}, \mathrm{Sr})$-doped $\mathrm{CeO}_{2}$ catalysts increased the ratio of electrophilic oxygen species $\left(\mathrm{O}_{2}{ }^{-}\right.$and $\left.\mathrm{O}_{2}{ }^{2-}\right)$ to nucleophilic oxygen species (lattice $\mathrm{O}^{2-}$ ) on the catalyst surface and Osada et al. [36] were able to show that $\mathrm{O}_{2}$ - species can remain stable up to $750{ }^{\circ} \mathrm{C}$ while reacting with $\mathrm{CH}_{4}$ over $\mathrm{Y}_{2} \mathrm{O}_{3}-\mathrm{CaO}$ catalysts.

\subsection{Charge analysis of dioxygen on La-O clusters}

As shown in Table 2, the charge and spin density of $\mathrm{O}_{2}(\mathrm{~T})$ in the triplet state are 0.00 and 2.00, respectively, while those of $\mathrm{O}_{2}{ }^{-}$are -1.00 and 1.00, respectively, and those of $\mathrm{O}_{2}{ }^{2-}$ are -2.00 and 0.00 , respectively. The charges on the dioxygen species of LM1-SA and LM1-TA are -0.43 and -0.82 , respectively, and their spin densities are 0.00 and 1.04 , respectively, which are comparable to those of $\mathrm{O}_{2}{ }^{-}$. LM8-SA has a charge of -1.49 and a spin density of 0.00 on the atoms of its dioxygen species, which is consistent with the values associated with $\mathrm{O}_{2}{ }^{2-}$. In the case of

Table 2

\begin{tabular}{|c|c|c|c|c|c|c|c|c|c|}
\hline \multirow{3}{*}{ Species } & \multirow{3}{*}{ Identity } & \multicolumn{4}{|c|}{ Atomic charge } & \multicolumn{4}{|c|}{ Atomic spin density } \\
\hline & & \multicolumn{2}{|c|}{ 1st dioxygen } & \multicolumn{2}{|c|}{ 2nd dioxygen } & \multicolumn{2}{|c|}{ 1st dioxygen } & \multicolumn{2}{|c|}{ 2nd dioxygen } \\
\hline & & 01 & 02 & 03 & 04 & 01 & 02 & 03 & 04 \\
\hline$\overline{\mathrm{O}_{2}(\mathrm{~T})}$ & $\mathrm{O}_{2}$ & 0.00 & 0.00 & - & - & 1.00 & 1.00 & - & - \\
\hline $\mathrm{O}_{2}(\mathrm{~S})$ & $\mathrm{O}_{2}$ & 0.00 & 0.00 & - & - & 0.00 & 0.00 & - & - \\
\hline $\mathrm{O}_{2}^{-}$ & $\mathrm{O}_{2}^{-}$ & -0.50 & -0.50 & - & - & 0.50 & 0.50 & - & - \\
\hline $\mathrm{O}_{2}^{2-}$ & $\mathrm{O}_{2}{ }^{2-}$ & -1.00 & -1.00 & - & - & 0.00 & 0.00 & - & - \\
\hline LM1-SA & $\mathrm{O}_{2}^{-}$ & -0.12 & -0.31 & - & - & 0.00 & 0.00 & - & - \\
\hline LM8-SA & $\mathrm{O}_{2}{ }^{2-}$ & -0.74 & -0.75 & - & - & 0.00 & 0.00 & - & - \\
\hline LM1-TA & $\mathrm{O}_{2^{-}}^{-}$ & -0.41 & -0.41 & - & - & 0.52 & 0.52 & - & - \\
\hline LM1-SB & $\mathrm{O}_{2^{-}}+\mathrm{O}_{2}^{-}$ & -0.16 & -0.50 & -0.17 & -0.39 & 0.00 & 0.00 & 0.00 & 0.00 \\
\hline LM2-SB & $\mathrm{O}_{2}^{2-}+\mathrm{O}_{2-}^{-}$ & -0.77 & -0.78 & -0.20 & -0.26 & 0.00 & 0.00 & 0.00 & 0.00 \\
\hline LM1-TB & $\mathrm{O}_{2^{-}}+\mathrm{O}_{2^{-}}$ & -0.35 & -0.49 & -0.40 & -0.41 & 0.42 & 0.57 & 0.51 & 0.53 \\
\hline LM2-TB & $\mathrm{O}_{2}^{2-}+\mathrm{O}_{2}$ & -0.80 & -0.80 & 0.09 & -0.08 & 0.01 & -0.01 & 0.92 & 1.06 \\
\hline
\end{tabular}

NBO charge and Mulliken spin density values of the oxygen atoms of selected oxygen species on La-O clusters. 
the two dioxygen species on the La- 0 cluster, the charges on the dioxygen species of LM1-SB are -0.66 and -0.56 for the first and the second dioxygen species, respectively, while the corresponding values of LM2-SB are -1.55 and -0.46 , which are comparable to those of $\left(\mathrm{O}_{2}{ }^{-}, \mathrm{O}_{2}^{-}\right)$and $\left(\mathrm{O}_{2}{ }^{2-}, \mathrm{O}_{2}^{-}\right)$, respectively. The spin densities of these species are all zero because they are in the singlet state. Similarly, the charges on the dioxygen species of LM1-TB in the triplet state are -0.84 and -0.81 for the first and second dioxygen species respectively, and the corresponding values of LM2-TB in the triplet state are -1.60 and 0.01 . The spin densities on the dioxygen species of LM1-TB in the triplet state are 0.99 and 1.04 for the first and second dioxygen species, respectively, while the corresponding values of LM2-TB in the triplet state are 0.00 and 1.98, which are similar to those of $\left(\mathrm{O}_{2}{ }^{-}, \mathrm{O}_{2}-\right)$ and $\left(\mathrm{O}_{2}{ }^{2-}, \mathrm{O}_{2}\right)$, respectively. Hence, our analysis of charges and spin densities supports the previously noted assignments of the dioxygen species on the La-O clusters.

\section{Conclusions}

With regard to the evolution of single dioxygen species over La-O clusters at low oxygen concentrations, there exists only a single pathway by which superoxides can transition to peroxides via the formation of a series of ozonide species. During interactions of two superoxide species over La-O clusters, there are two pathways: singlet and triplet. In the triplet path, superoxide species on the clusters are disproportionately converted into peroxides and molecular oxygen such that the superoxide species are in rapid exchange with the peroxide species. However, in the singlet path, the superoxide species are directly transformed into the peroxide species only in the presence of another superoxide species, which behaves as a spectator. In such instances, the conversion barrier between superoxide and peroxide is rather high and both species are quite stable. Peroxide species on La-O clusters are more stable than superoxide species.

\section{References}

[1] Hermans I, Spier E S, Neuenschwander U, Turra N, Baiker A. Top Catal, 2009, 52: 1162
[2] Zanthoff H W, Buchholz S A, Pantazidis A, Mirodatos C. Chem Eng Sci, 1999, 54: 4397

[3] Ferreira V J, Tavares P, Figueiredo J L, Faria J L. Ind Eng Chem Res, 2012, 51: 10535

[4] Wan H L, Zhou X P, Weng W Z, Long R Q, Chao Z S, Zhang W D, Chen M S, Luo J Z, Zhou S Q. Catal Today, 1999, 51: 161

[5] Shvets V A, Vorotyntsev V M, Kazanskii V B. Kinet Katal, 1969, 10: 356

[6] Kazanskii V B. Kinet Katal, 1977, 18: 43

[7] Au C T, He H, Lai S Y, Ng C F. J Catal, 1996, 163: 399

[8] Palmer M S, Neurock M, Olken M M. J Am Chem Soc, 2002, 124: 8452

[9] Valentin C D, Pacchioni G, Abbet S, Heiz U.J Phys Chem B, 2002, 106: 7666

[10] Louis C, Chang T L, Kermarec M, Le Van T, Tatibouet J M, Che M. Catal Today, 1992, 13: 283

[11] Louis C, Chang T L, Kermarec M, Le Van T, Tatibouet J M, Che M. Colloids Surf A, 1993, 72: 217

[12] Diwald O, Knozinger E.J Phys Chem B, 2002, 106: 3495

[13] Xia W, Li J H, Weng W Z, Wan H L. Chem Phys Lett, 2006, 423: 427

[14] Fujita S, Suzuki K, Ohkawa M, Mori T, Iida Y, Miwa Y, Masuda H, Shimada S. Chem Mater, 2003, 15: 255

[15] Chen H Y, El-Malki E M, Wang X, van Santen R A, Sachtler W M H.J Mol Catal A, 2000, 162: 159

[16] El-Malki E M, Werst D, Doan P E, Sachtler W M H. J Phys Chem B, 2000, 104: 5924

[17] Cotton F A, Wilkinson G, Murillo C A, Bochmann M. Advanced Inorganic Chemistry. Sixth ed. New York: John Wiley \& Sons, 1999. $465-471$

[18] Gao Z X, Kim H S, Sun Q Stair P C, Sachtler W M H. J Phys Chem B, 2001, 105: 6186

[19] Willson S P, Andrews L. J Phys Chem A, 1999, 103: 3171

[20] Wang Z C, Yin S, Bernstein E R. J Phys Chem A, 2013, 117: 2294

[21] Frisch M J, Trucks G W, Schlegel H B, Scuseria G E, Robb M A, Cheeseman J R, Zakrzewski V G, Montgomery J A, Jr., Stratmann R E, Burant J C, Dapprich S, Millam J M, Daniels A D, Kudin K N, Strain M C, Farkas 0, Tomasi J, Barone V, Cossi M, Cammi R, Mennucci B, Pomelli C, Adamo C, Clifford S, Ochterski J, Petersson G A, Ayala P Y, Cui Q Morokuma K, Malick D K, Rabuck A D, Raghavachari K, Foresman J B, Cioslowski J, Ortiz J V, Stefanov B B, Liu G, Liashenko A, Piskorz P, Komaromi I, Gomperts R, Martin R L, Fox D J, Keith T, Al-Laham M A, Peng C Y, Nanayakkara A, Gonzalez C, Challacombe M, Gill P M W, Johnson B G, Chen W, Wong M W, Andres J L, Head-Gordon M, Replogle E S, Pople J A.

\section{Graphical Abstract}

Chin. J. Catal., 2013, 34: 2130-2137 doi: 10.1016/S1872-2067(12)60694-9

Pathways between superoxide and peroxide species on small La-O clusters

Wensheng Xia*, Da Zhang, Weizheng Weng, Huilin Wan* Xiamen University

Superoxide species over La-O clusters are in rapid exchange with peroxide species in the triplet channel while superoxide and peroxide species are both relatively stable in the singlet channel.

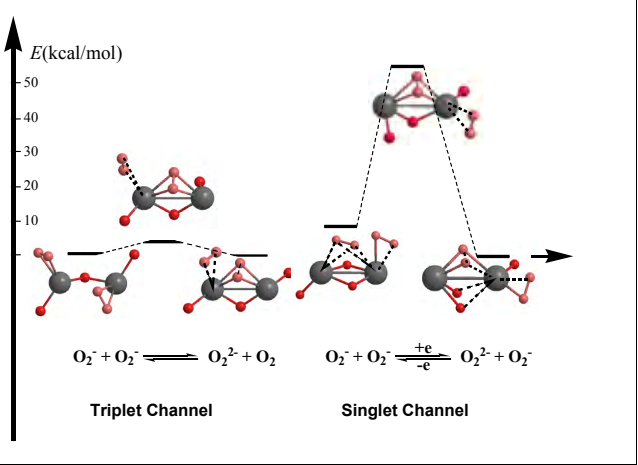


Gaussian 98, revision A.11, 1998, Gaussian, Inc.

[22] Vosko S H, Wilk L, Nusair M. Can J Phys, 1980, 58: 1200

[23] Becke A D. J Chem Phys, 1993, 98: 5648

[24] Perdew J P, Wang Y. Phys Rev B, 1992, 45: 13244

[25] Hay P J, Wadt W R. J Chem Phys, 1985, 82: 299

[26] Hehre W J, Ditchfield R, Pople J A. J Chem Phys, 1972, 56: 2257

[27] Krupenie P H.J Phys Chem Ref Data, 1972, 1: 423

[28] Ervin K M, Anusiewicz I, Skurski P, Simons J, Lineberger W C. J Phys Chem A, 2003, 107: 8521

[29] Kantorovich L N, Gillan M J. Surf Sci, 1997, 374: 373

[30] Fourier R, De Pristo A E. J Chem Phys, 1992, 96: 1183

[31] Shimanouchi T. Table of Molecular Vibrational Frequencies,
Consolidated Vol. 1 National Standard Reference Data Series 39. Washington, D C: National Bureau of Standards, 1972

[32] Weng W Z, Wan H L, Li J M, Cao Z X. Angew Chem Int Ed, 2004, 43: 975

[33] Jing X L, Chen Q C, He C, Zhu X Q, Weng W Z, Xia W S, Wan H L. Phys Chem Chem Phys, 2012, 14: 6898

[34] Huacuja R, Graham D J, Fafard C M, Chen C H, Foxman B M, Herbert D E, Alliger G, Thomas C M, Ozerov O V. J Am Chem Soc, 2011, 133: 3820

[35] Cho J, Woo J, Nam W. J Am Chem Soc, 2010, 132: 5958

[36] Osada Y, Koike S, Fukushima T, Ogasawara S, Shikada T, Ikariya T. Appl Catal, 1990, 59: 59

\title{
La-O小团簇上超氧物种与过氧物种间的连接途径
}

\author{
夏文生 ${ }^{*}$, 张 达, 翁维正, 万惠霖 ${ }^{*}$ \\ 厦门大学化学化工学院, 福建省理论与计算化学重点实验室, 醇醚酯清洁化工生产国家工程实验室, \\ 固体表面物理化学国家重点实验室, 福建厦门361005
}

摘要: 采用密度泛函理论方法考察了 $\mathrm{La}-\mathrm{O}$ 团簇上超氧物种与过氧物种间转化的连接途径. 单重态下, 团簇上单个超氧物种可通 过一系列臭氧物种转化为过氧物种, 且转化能垒较高; 三重态下, 单个超氧物种则并无与过氧物种间连接的途径. 然而, La-O团 簇上两超氧物种间的相互作用及其转化也具单重态和三重态两条途径. 三重态下, 超氧物种可很容易地转化为过氧物种 $\left(\mathrm{O}_{2}{ }^{-}+\right.$ $\mathrm{O}_{2}{ }^{-} \leftrightarrow \mathrm{O}_{2}{ }^{2-}+\mathrm{O}_{2}$ ), 超氧物种与过氧物种处于快速的交换状态之中; 单重态下, 超氧物种转化为过氧物种则需较高的活化能垒, 表 明在单重态下这些氧物种具有较高的稳定性.

关键词: 氧; 超氧; 过氧; 氧化锞; 密度泛函理论

收稿日期: 2013-07-04. 接受日期: 2013-08-26. 出版日期: 2013-11-20.

*通讯联系人. 电话: (0592)3658107; 传真: (0592)2183047; 电子信箱: wsxia@xmu.edu.cn

\#通讯联系人. 电子信箱: hlwan@xmu.edu.cn

基金来源：国家重点基础研究发展计划(973计划, 2010CB732303); 国家自然科学基金(21033006, 21373169, 20373054); 长江学者 和创新团队发展计划(IRT1036).

本文的英文电子版由Elsevier出版社在ScienceDirect上出版(http://www.sciencedirect.com/science/journal/18722067). 